\title{
Effects of Three Different Frequencies of Aerobic Physical Activity on Heart and Kidney Tissues in Type 2 Diabetes-Induced Rats
}

\author{
Tip 2 Diyabetik Sıçanlarda Üç Farklı Aerobik Fiziksel Aktivite Sıklığının \\ Kalp ve Böbrek Dokuları Üzerine Etkileri
}

\author{
Nuray ALACA $\odot$, Serap USLU $\odot$, Gulcin BASDEMIR $\odot$, Guldal GULEC SUYEN $\odot$, Dilek OZBEYLi $\odot$, \\ Hizir KURTEL ๑
}

Ethics Committee Approval: This study approved by the Acibadem University Ethics Committee for Animal Research, 9 August 2019, 2017/26.

Conflict of interest: One of the authors of this article is an Editorial Board Member of this journal and was excluded from all evaluation steps. The other authors declare that they have no conflict of interest. Funding: This research was supported by the Mehmet Ali Aydinlar Acibadem University Scientific Research Project Commission (Project no. 2017/01/13).

Informed Consent: Not Applicable.
Cite as: Alaca N, Uslu S, Basdemir G, Gulec Suyen G, Ozbeyli D, Kurtel H. Effects of three different frequencies of aerobic physical activity on heart and kidney tissues in type 2 diabetes-induced rats. Medeniyet Med J. 2019;34:252-62.

\begin{abstract}
Objective: Exercise has many beneficial effects in the treatment and prevention of Type 2 Diabetes Mellitus (T2DM). The aim of this study was to evaluate the effect of physical activities with different frequencies performed within a total total duration of one week on the heart and kidney tissues and vascular endothelial growth factor (VEGF) expressions in experimental T2DM model.

Method: Rats ( $n$ : 30) were divided into sedentary control (SC), sedentary T2DM (SD), T2DM and continuous exercise (DEc, $30 \mathrm{~min} /$ day, 5 days/week), T2DM and short bouts exercise (DEsb, $3 \times 10 \mathrm{~min} /$ day, 5 days/week), T2DM and weekend warrior exercise (DEww, 35+40 min/day, 2 days/week) groups. Rats were administered streptozotocin $(65 \mathrm{mg} / \mathrm{kg})$ and nicotinamide $(110$ $\mathrm{mg} / \mathrm{kg}$ ) through intraperitoneal route. After 6-weeks of swimming exercise (total duration 150 $\mathrm{min} /$ week), biochemical analyzes were performed to measure oral glucose tolerance test, insulin sensitivity and cytokines. Histopathological and immunohistochemical analyses [VEGF, capillary density, Transforming growth factor beta (TGF- $\beta$ )] were performed in heart and kidney tissues. Results: Compared with sedentary T2DM rats, significant improvements were observed in all exercise groups in terms of blood glucose level, insulin sensitivity, capillary density in heart tissue, VEGF expressions in tissues, TGF- $\beta$ expressions in kidney tissue and all histopathological analysis $(p<0.05)$.

Conclusion: This study shows that physical activity at various frequencies may significantly ameliorate harmful effects of T2DM on heart and kidney tissue without significant differences between exercise frequencies, provided that the total duration of aerobic exercise remains the same (150 min/week).
\end{abstract}

Keywords: Physical activity, short bouts of exercise, type 2 diabetes mellitus, vascular endothelial growth factor, weekend warrior

öz

Amaç: Tip 2 Diabetes Mellitus (T2DM) tedavisinde ve önlenmesinde egzersizin birçok faydalı etkisi vardır. Bu calısmanın amacı, deneysel T2DM modelinde haftalık toplam süre aynı olmak şartıyla farklı sıklıklarla yapılan fiziksel aktivitenin kalp ile böbrek dokuları ve vasküler endotelyal büyüme faktör ekspresyonu üzerindeki etkisini değerlendirmektir.

Yöntem: SIçanlar (n:30) sedenter kontrol (SK), sedenter T2DM (SD), T2DM ve devamlı egzersiz (DEd, $30 \mathrm{dk}$./gün, $5 \mathrm{gün} / \mathrm{hafta)}$, T2DM ve kısa aralıklı egzersiz (DEka, $3 \times 10 \mathrm{dk}$./gün, 5 gün/hafta), T2DM ve hafta sonu savaş̧ıları egzersiz (DEhs, 35+40 dk./gün, 2 gün/hafta) olarak gruplara ayrıldı. Siçanlara intraperitoneal olarak streptozosin $(65 \mathrm{mg} / \mathrm{kg})$ ve nikotinamid $(110 \mathrm{mg} / \mathrm{kg})$ uygulanarak T2DM indüklendi. 6 haftalık (toplam süre 150 dk./hafta) yüzme egzersizinden sonra oral glukoz tolerans testi, insülin duyarlılığı ve sitokinlerin ölçümü için biyokimyasal analizler yapıldı. Kalp ve böbrek dokularında histopatolojik ve immünohistokimyasal analizler [VEGF, kapiller yoğunluk, dönüștürücü büyüme faktörü beta (TGF- $\beta$ )] yapıldı.

Bulgular: Sedenter diyabet sıçanlarına kıyasla, tüm egzersiz gruplarında kan şekeri seviyesi, insülin duyarlılığı, kalp dokusunda kılcal yoğunluğu, dokulardaki VEGF ifadeleri, böbrek dokusunda TGF- $\beta$ ifadeleri ve tüm histopatolojik analizlerde önemli iyileșmeler gözlendi $(p<0,05)$.

Sonuc: Bu çalıșmada, toplam aerobik egzersiz süresinin aynı kalması şartıyla (150 dk./hafta) farklı sıklıklarda yapılan aerobik fiziksel aktivitenin, T2DM'nin kalp ve böbrek dokusu üzerinde zararlı etkilerini önemli ölçüde iyileştirebileceğini göstermektedir.

Anahtar kelimeler: Fiziksel aktivite, kısa aralıklı egzersiz, tip 2 diabetes mellitus, vasküler endotel büyüme faktörü, haftasonu savaşçısı

(c) Copyright Istanbul Medeniyet University Faculty of Medicine. This journal is published by Logos Medical Publishing.

Licenced by Creative Commons Attribution-NonCommercial 4.0 International (CC BY-NC 4.0)
Received: 10 July 2019 Accepted: 5 September 2019 Online First: 27 September 2019

Corresponding Author: N. Alaca

ORCID: 0000-0003-3034-9388 Acibadem Mehmet Ali Aydinlar University, Department of Physiotherapy and Rehabilitation, Faculty of Health Sciences, Istanbul, Turkey

nuray.alaca@acibadem.edu.tr

S. Uslu

ORCID: 0000-0002-6613-527X

Istanbul Medeniyet University,

Department of Histology and Embryology, School of Medicine, Istanbul, Turkey

G. Basdemir ORCID: 0000-0002-2104-8957 Okan University, Department of Pathology, School of Medicine, Istanbul, Turkey

G. Gulec Suyen ORCID: 0000-0003-0863-1547 Acibadem Mehmet Ali Aydinlar University, Department of Physiology, School of Medicine, Istanbul, Turkey

D. Özbeyli

ORCID: 0000-0002-4141-6913 Marmara University, Department of Pathology Laboratory Techniques, Vocational School of Health Services, Istanbul, Turkey

H. Kurtel ORCID: 0000-0003-3633-7863 Marmara University, Department of Physiology, School of Medicine, Istanbul, Turkey

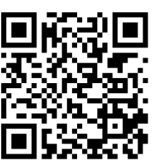




\section{INTRODUCTION}

Chronic hyperglycemia in Type 2 Diabetes Mellitus (T2DM) causes long term microvascular and macrovascular damage. It also leads to dysfunction and/or insufficiency in various organs such as heart and kidney. Coronary artery disease is the main reason of mortality and morbidity in T2DM patients ${ }^{1}$. Angiogenic factors including vascular endothelial growth factor (VEGF) which are response for vascular injury, tissue ischemia and hyperglycemia are related to diabetic microvascular complications ${ }^{2}$. VEGF causes pathophysiological and physiological sprouting, migration and tube formation in the cardiac endothelial cells ${ }^{3}$. The decrease of VEGF expression in diabetic cardiomyopathy has been related to the significant decline in capillary intensity and left ventricular (LV) dysfunction ${ }^{2}$. In streptozotocin (STZ)-induced diabetic animals, it has been shown that there is a decrease in myocardial VEGF mRNA expression and physical exercise increases the VEGF expression in the cardiac tissue ${ }^{4}$.

As another complication of diabetes, diabetic nephropathy, is the main cause of end-stage renal failure. In the early stages of diabetic nephropathy the key changes are the increase in renal dimensions, glomerular volume and renal functions. During the progress of nephropathy, accumulation of glomerular extracellular matrix, albuminuria, glomerular sclerosis and tubular fibrosis are observed. The last stage, is characterized by proteinuria, hypertension and progressive renal failure ${ }^{2,5}$. The dysregulation of renal VEGF is thought to be the triggering factor in the pathophysiology of diabetic nephropathy. It has been suggested that VEGF inhibition reverses the structural and functional changes in experimental diabetic nephropathy, indicating a possible therapeutic target option ${ }^{5}$.

Insulin resistance and glucose intolerance have been found less frequently in physically active people ${ }^{\sigma}$. Today it is known that physical activity
(PA) decreases the rates of mortality due to cardiovascular diseases in diabetic patients via glycemic control ${ }^{7}$. It has been reported that exercise has ameliorating effects on nephropathy probably related to the reduction of hyperglycemia ${ }^{2}$. Today, physical activity guidelines recommend moderate intensity aerobic activities for at least 150 minutes/week and vigorous intensity aerobic activities or equivalent combinations for at least 75 minutes/week in all healthy adults or diabetic persons. The daily target of $\mathbf{3 0}$ minute moderate intensity aerobic activity can be achieved adding up activities lasting at least 10 minutes. The aim of intermittent approach is to ease the adaptation and continuity of the sedentary population to exercise $^{8-10}$. Although available literature suggest that accumulated exercise has potential benefits, there are uncertainities on how to combine the frequency, intensity and duration of $\mathrm{PA}^{11}$. Some individuals who have time constraints because of their work and social activities have chosen to complete the expected exercise duration in one or two days of week, especially weekends. These individuals are called "weekend warriors". This type of activity is frequently preferred, though it is not found in the guidelines. Information about the benefits and harms of this type of activity is very limited ${ }^{8,12}$. In our previous research, continuous, short bouts and the weekend warrior exercise models have been applied in a rat model of T2DM and the effect of these different exercise frequencies on the parameters of T2DM, diabetic myopathy and muscle mitochondrial enzymes have been compared for the first time. We found that, all frequencies of exercise have beneficial effects on these parameters and none one of the exercises is superior to the others ${ }^{8}$. Our observations on muscle and liver tissue ${ }^{13}$ lead us to hypothesize that intermittent exercise approach can also be benefial on the outcome of heart and kidney injury induced by T2DM. Furthermore, for the abovementioned reasons there may be a link between VEGF metabolism and experimental T2DM model and if so, benefits of intermittent exercise may be related with the altered VEGFstate. Therefore, in 
this study we aimed to investigate the effect of PA with different frequencies but performed within the same total durations on the heart and kidney tissues and VEGF expressions after development of experimental T2DM.

\section{MATERIALS and METHODS}

Ethical approval has been obtained from Acibadem University Ethics Committee for Animal Research (9 August 2019, 2017/26).

\section{Animal and study design}

For our study, Sprague Dawley male rats (n:30) weighing 300-350 gr. have been provided from Acibadem University Laboratory Animal Research Center. Animals were housed under standart conditions with free access to food and water. The animals were randomly divided into five groups as follows ( $\mathrm{n}=6$ in each group):

i. Sedentary control group (SC)

ii. Sedentary T2DM group (SD)

iii. T2DM and continuous exercise group (DEC)

iv. T2DM and short bouts exercise group (DEsb)

v. T2DM and weekend warrior exercise group (DEww)

\section{Induction of T2DM}

To induce T2DM, intraperitonal injections of NA (110 mg/kg; Sigma, Saint-Louis, MO, USA) dissolved in saline, followed 15 minutes by STZ (65 $\mathrm{mg} / \mathrm{kg}$; Sigma, Saint-Louis, MO, USA) diluted in $0.1 \mathrm{M}$ sitrat buffer ( $\mathrm{pH}: 4.5)$ were applied, following overnight fasting. Both of the vehicles have been applied through intraperitonal route only to the SC rats ${ }^{14}$. One week later, after 12 hours of overnight fasting, blood glucose levels (FBG) have been measured by glucometer (Accutrend Plus; Roche, Mannheim, Germany) from the tail vein. Rats with FBG levels over $126 \mathrm{mg} / \mathrm{dl}$ have been considered as $\mathrm{T}_{2} \mathrm{DM}^{15}$. Rats with FBG levels over $300 \mathrm{mg} / \mathrm{dl}$ were excluded from the study since they could have difficulty in completing the exercise schedule.

\section{Exercise protocol}

One week after T2DM induction, the animals except the sedentary groups started to apply swimming protocol. During the adaptation period, they were put in a Morris water tank (60 cmx150 $\mathrm{cm} \times 45 \mathrm{~cm}$; water temperature $32 \pm{ }^{\circ} \mathrm{C}$ ) for 10 minutes in the first day and were accustomed to swimming by increasing the exercise period by 10 minutes every day until they were able to exercise for 30 or 40 minutes without interruption. Group DEsb received 10 minute swimming sessions each day. After the adaptation phase, we switched to the exercise phase which continued for six weeks (total $150 \mathrm{~min} /$ week) as follows:

i. DEc: 30 minutes/5 days a week

ii. DEsb: $3 \times 10$ minutes/5 days a week (exercises with 3 hour intervals during the day)

iii. DEww: 35+40 minutes/day/2 consecutive days a week (Monday, Tuesday)/6 weeks

\section{Oral glucose tolerance test}

On the last day of exercise oral glucose tolerance test was performed to all rats. Then glucose was administered ( $2 \mathrm{~g}$ /body weight; intragastrically) under isoflurane anesthesia and glycemia was measured at 0,30 and 60 min after glucose $\operatorname{load}^{16}$.

\section{Collection of blood and tissue samples}

Twenty four hours after the last exercise, blood was drawn from the hearts of all animals under sodium pentobarbital $(50 \mathrm{mg} / \mathrm{kg})$ anesthesia and animals were sacrificed by cervical dislocation. The hearts and kidneys of all animals were immediately removed. Serum samples obtained by centrifugation at $3000 \mathrm{rpm}$ for 10 minutes were stored at $-80^{\circ} \mathrm{C}$.

\section{Assessment of insulin sensitivity}

Serum levels of insulin were determined using rat insulin ELISA kit (Eastbiopharm, Hangzhou, China). The quantitative insulin sensitivity check index (QUICKI) was used to measure the degree of insulin resistance. This method is based on mathematical calculations on the fasting glucose 
and insulin values obtained at the same time. Values less than $0.335 \mathrm{mg} / \mathrm{dL}$ indicate insulin resistance. QUICKI is calculated by the following equations ${ }^{17}$ :

QUICKI $=1 \div(\log$ glucose $+\log$ insulin $)$

\section{Determination of cytokines and total antioxi- dant capacity (T-AOC)}

Serum levels of tumor necrosis factor alpha (TNF- $\alpha$ ) and interleukin-6 (IL-6) were measured using a rat TNF- $\alpha$ ve IL- 6 ELISA kit, respectively (eBioscience, San Diego, CA, USA). Serum level of T-OAC was determined using rat T-OAC ELISA kit (Eastbiopharm, Hangzhou, China).

\section{Histopathological Analysis}

Left kidneys and LV were used for histopathological analysis. Heart sections were analyzed by light microscopy after embedding in paraffin, blocks, followed by standard hematoxylin and eosin (H\&E) staining and Picrosirious red (PR) to evaluated fibrosis. Immunohistochemical analysis of transforming growth factor beta (TGF- $\beta$ ), CD31, and VEGF was performed.

Left kidneys were dissected and fixed in $10 \%$ buffered formalin and stained with $\mathrm{H} \& \mathrm{E}$ and periodic acid Schiff (PAS) stain was used for the evaluation. of basement membrane. Immunohistochemical analyses of TGF $-\beta$ and VEGF were performed.

\section{Histomorphometrical Analyses Size of Cardiomyocytes}

Five-micrometer serial sections of LV were measured with H\&E to determine the cross-sectional area of cardiomyocytes. In longitudinally oriented cardiomyocytes, cross-sectional area of cardiomyocytes was measured in a double-blind fashion from five different sites of each section at $\times 400$ magnification ${ }^{2}$.

\section{Fibrotic Area}

Ten consecutive LV slides of each animal in each group were counted for their fibrotic areas. Square grid placed on transparent paper was used for measurement of fibrosis in LV. Then it was quantified as a percentage of the total area of LV and a mean value for each fibrotic area was calculated $\left(\mathrm{cm}^{2} / 675 \mathrm{~cm}^{2}\right.$ area). Ten microscopic fields per animal were scanned under X 400 magnification All of the analyses were performed in a blinded fashion ${ }^{18}$.

\section{Thickness of Basement Membrane}

Thickness of basement membranes were evaluated histomorphometrically via PAS staining serial sections in all animals with an image analysis system $^{19}$. All histomorphometric analysis were performed after the images were transferred by light microscope (Olympus BX53, bright-field microscope, America Inc., USA) into a computer. Serial sections in each rats were quantified at a magnification of $X 40$ for each section after processing by a semiautomatic digitizer The University of Texas Health Science Center At Santorino (UTHSCSA Image Tool for Windows Version 1.28) ${ }^{13}$.

\section{Immunohistochemical analyses}

Formalin-fixed paraffin-embedded hearts and kidneys were sectioned, and 5 - $\mu$ m-thick sections were used for detection of CD31 (Cell Marque, clone: Monoclonal, dilution: $1: 100$, USA), TGF- $\beta$ (ThermoFisher Scientific, clone: Monoklonal, dilution: 1:100, USA), VEGF (Spring Bioscience, clone: N/A, dilution: 1:100, USA) expressions by immunohistochemistry via the Leica Bond-Max automation and Leica Refine detection kit (Leica Biosystems, USA). Analyses were performed blindly by a histologist. The brown precipitate formed due to the DAB used during the immunohistochemistry showed a positive reaction for the primary antibodies. Semi-quantitative HSCORE analysis was used to evaluate immunohistochemical results when comparing the groups. The following equation was used to calculate HSCORE: HSCORE $=\Sigma \mathrm{Pi}(\mathrm{i}+1)$, where $\Sigma$ is the intensity of labelling with a value of 1,2 or 3 , (weak, moderate, or strong, respectively) and $\mathrm{Pi}$ is the percentage of labelled cells for each intensity, varying from $0 \%$ to $100 \%{ }^{18,19}$. 


\section{Statistical analyses}

Statistical analyses were performed with GraphPad Prism 6.0 (GraphPad Software, San Diego, CA, USA). All data were expressed as the mean $\pm \mathrm{SD}$. Data were compared using analysis of variance analysis (ANOVA) and then Tukey's multiple comparison tests. For all studies, $\mathrm{P}<0.05$ was considered significant.

\section{RESULTS}

\section{OGTT and Insulin sensitivity}

Table 1 summarizes the results of OGTT. FBG of $8^{\text {th }}$ week in the SD group were significantly higher compared to the SC group $(p<0.001)$. In contrast, FBG in the DEc, DEsb and DEww groups decreased significantly compared with the SD group in the $8^{\text {th }}$ week of the study $(p<0.001$, Table 1$)$. OGTT levels in all T2DM groups were significantly increased compared to the SC group on the $30^{\text {th }}$ ( $p<0.01$ for DEww; $p<0.001$ for SD, DEc and DEsb) and $60^{\text {th }}$ minutes ( $p<0.01$ for DEc; $p<0.001$ for SD, DEsb, DEww).

Compared with the SD group, QUICKI was significantly lower in the SC group $(p<0.001)$, whereas QUICKI was significantly higher in all exercise groups (all $p<0.05$, Table 1 ).

\section{Cytokines and T-AOC levels}

Serum levels of TNF $-\alpha(p<0.01$ for SD, $p<0.05$ for all exercise groups) and IL-6 (all $p<0.01$ ) were significantly elevated in all T2DM groups compared to the SC group (Table 1). In the SD group, serum levels of T-AOC were significantly lower than the SC group $(p<0.05)$. These levels significantly increased in the DEc and DEww groups with respect to the SD group (both $p<0.01$, Table 1 ).

\section{Histopathological Analysis}

Cardiomyocyte size increased significantly in all exercise groups compared to SC and SD groups (all $p<0.001$, Figures 1 and 2A). Compared to the SC group, fibrotic area was significantly elevated in SD group $(p<0.01)$. However, it was significantly lower in the DEc, DEsb and DEww groups (all $\mathrm{p}<0.05$ ) compared with the SD group (Figures 1 and $2 \mathrm{~B}$ ). Thickness of renal basement membranes was significantly higher in the SD group than SC group $(p<0.001)$, whereas they were significantly lower in all exercise groups wirelative to the SD group (all $\mathrm{p}<0.001$. Figures 1 and $2 \mathrm{C}$ ).

Histopathological examination of kidney tissue samples revealed completely disorganized, glomerular architecture with little space between glomerular capillaries, expanded mesangium, narrowed capsular space in the Bowman's capsule and thickened basement membranes in the

Table I. Effect of exercise frequencies on oral glucose tolerance test, QUICKI, cytokines and T-AOC in experimental type 2 diabetes induced rats.

\begin{tabular}{|c|c|c|c|c|c|}
\hline & SC & SD & DEc & DEsb & DEww \\
\hline \multicolumn{6}{|l|}{ OGTT (mg/dl) } \\
\hline Fasting BGL of $8^{\text {th }}$ week & $66.50 \pm 12.08$ & $293.00 \pm 164.79^{* * *}$ & $129.23 \pm 30.10^{+++}$ & $104.80 \pm 31.27^{+++}$ & $138.17 \pm 53.72^{+++}$ \\
\hline $30 \mathrm{~min}$ & $134.17 \pm 37.09$ & $305.33 \pm 142.76^{* * *}$ & $318.00 \pm 42.48^{* * *}$ & $315.20 \pm 101.17^{* * *}$ & $259.83 \pm 53.66^{* *}$ \\
\hline $60 \mathrm{~min}$ & $127.17 \pm 12.47$ & $468.00 \pm 142.76^{* * *}$ & $413.66 \pm 89.78^{* *}$ & $345.20 \pm 106.54 * *$ & $378.66 \pm 93.46^{* * *}$ \\
\hline QUICKI & $0.38 \pm 0.01$ & $0.3 \pm 0.02^{* * *}$ & $0.34 \pm 0.02^{+}$ & $0.35 \pm 0.01^{+}$ & $0.34 \pm 0.01^{+}$ \\
\hline Serum TNF- $\alpha(\mathrm{pg} / \mathrm{mL})$ & $12.57 \pm 1.10$ & $17.87 \pm 2.25^{* *}$ & $15.39 \pm 3.00^{*}$ & $15.67 \pm 1.50^{*}$ & $15.37 \pm 2.08^{*}$ \\
\hline Serum IL-6 (pg/mL) & $22.17 \pm 8.59$ & $57.00 \pm 16.75^{* *}$ & $45.67 \pm 19.63^{* *}$ & $48.78 \pm 20.49 *$ & $51.17 \pm 12.19^{* *}$ \\
\hline Serum T-AOC $(\mathrm{nmol} / \mathrm{mL})$ & $10.52 \pm 0.64$ & $9.58 \pm 0.42^{*}$ & $11.38 \pm 1.05^{++}$ & $9.95 \pm 1.74$ & $11.45 \pm 1.04^{++}$ \\
\hline
\end{tabular}

OGTT, oral glucose tolerance test, QUICKI, quantitative insulin sensitivity check index; IL-6, interleukin 6; TNF- $\alpha$, tumor necrosis factor alfa; T-AOC, total antioxidant capacity, SC, sedentary control group; SD, sedentary T2DM group; DEc, T2DM and continuous exercise group; DEsb, T2DM and short bouts exercise group; DEWw, T2DM and weekend warrior exercise group. Data are reported as means $\pm S D$ of 6 animals in each group. " $p<0.05, " p<0.01, " p<0.001$ compared with sedentary control group. ${ }^{+} p<0.05,{ }^{++} p<0.01,{ }^{++} p<0.001$ compared with sedentary T2DM group. 


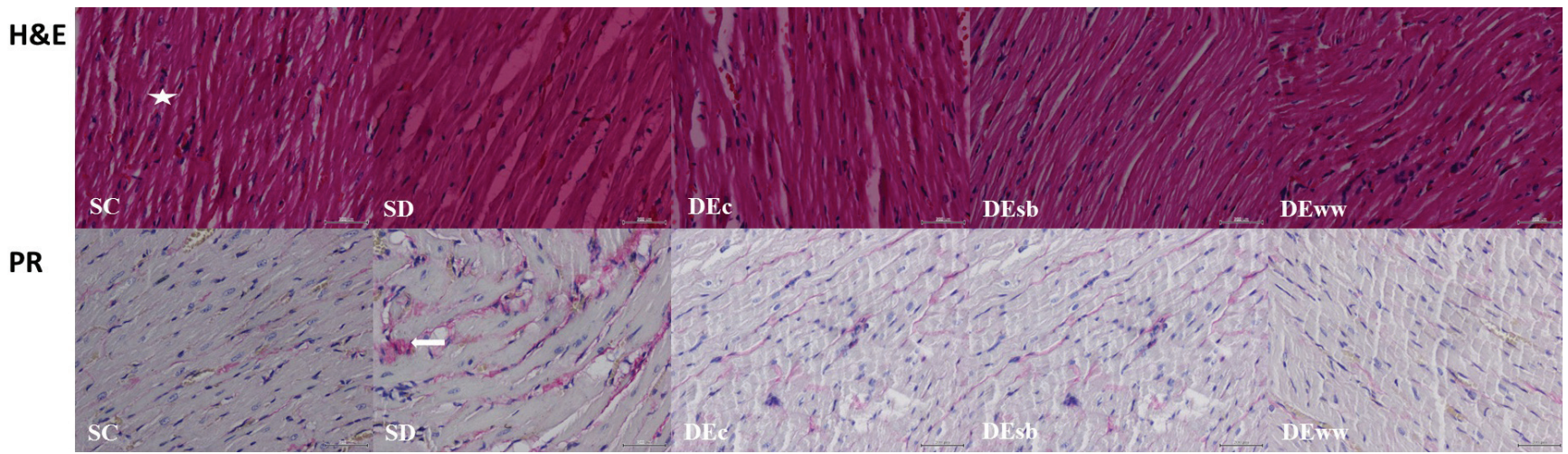

Figure 1. Effect of exercise frequencies on heart tissue in experimental type 2 diabetes induced rats.

$H \& E$, Hematoxylin eosin staining X4O; asterisk: myofibril; PR, picrosirius red staining X4O; Arrow: fibrosis. Bars, $50 \mu$ m; SC, sedentary control group; SD, sedentary T2DM group; DEc, T2DM and continuous exercise group; DEsb, T2DM and short bouts exercise group; DEWw, T2DM and weekend warrior exercise group.

A
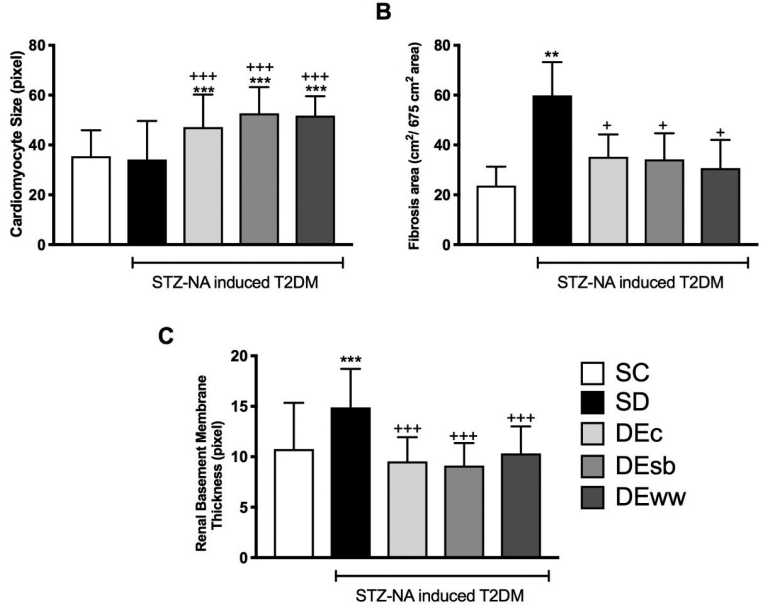

Figure 2. Effect of exercise frequencies on cardiomyocyte size, fibrosis area and renal basement membrane thickness in experimental type 2 diabetes induced rats.

A: cardiomyocyte size, B: fibrosis area, C: renal basement membrane thickness; SC, sedentary control group; SD, sedentary T2DM group; DEC, T2DM and continuous exercise group; DEsb, T2DM and short bouts exercise group; DEww, T2DM and weekend warrior exercise group. Data are reported as means $\pm S D$ of 6 animals in each group. " $p<0.05$, $" p<0.01, "{ }^{* * *} p<0.001$ compared with sedentary control group. ${ }^{+} p<0.05,{ }^{++} p<0.01,{ }^{++} p<0.001$ compared with sedentary T2DM group.

SD group (Figure 3). In all exercise groups, glomerular architecture was more similar to that of SC group rather than SD group. Spaces between glomerular capillaries and capsular area in the Bowman's capsule were enlarged and basement membrane was thinner. There were no significant microscopic differences between exercise groups (Figure 3).

\section{Immunohistochemical analysis}

VEGF expressions in the heart tissue were significantly increased in all exercise groups compared with the SC and SD groups (all $p<0.05$, Figures 4 and $5 A$ ). TGF- $\beta$ expressions in the heart tissue were significantly higher in the SD, DEsb and DEww groups $(p<0.05)$ relative to SC group. Compared to the SD group TGF- $\beta$ expressions in the heart tissue decreased in the DEc group $(p<0.05$, Figures 4 and 5B). CD31 expressions in the heart tissue were significantly reduced in the SD compared with SC group ( $p<0.01)$, whereas CD31 expressions were higher in the DEc $(p<0.01)$, DEsb $(p<0.05)$ and DEww $(p<0.05)$ groups compared with the SD group (Figure 4 and $5 \mathrm{C}$ ).

VEGF expressions in the renal tissue were significantly increased in the T2DM groups than in the SC group (all $p<0.001$, Figures 3 and 5D). Compared to the SD group, VEGF expressions in the renal tissue significantly decreased in all exercise groups (all $p<0.001$, Figures 3 and $5 D$ ). TGF- $\beta$ expressions in the renal tissue were significantly elevated in in all T2DM groups $(p<0.001$ for $S D$, $p<0.01$ for DEc and $p<0.05$ for DEsb and DEww) compared to the SC group, whereas TGF- $\beta$ expressions in the renal tissue were significantly lower in all exercise groups $(p<0.05$ for DEc and $\mathrm{p}<0.01$ for DEsb and DEww) than in the SD group (Figure 3 and 5E). 


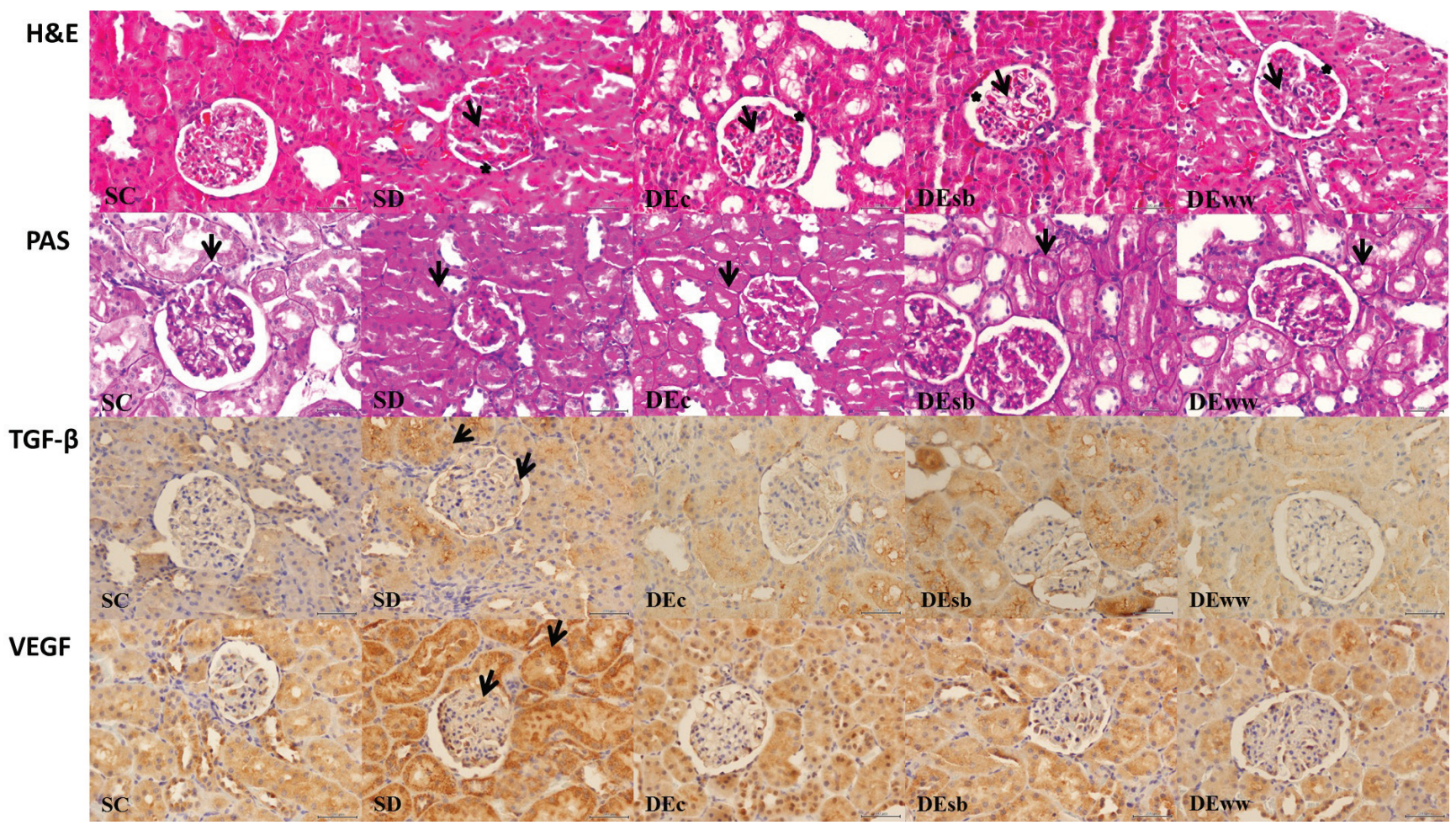

Figure 3. Effect of exercise frequencies on kidney tissue in experimental type $\mathbf{2}$ diabetes induced rats.

H\&E, Hematoxylin eosin staining X4O; arrow: glomerular architecture and expanding mesangium; PAS, Periodic acidSchiff stain X4O; arrow: Basal membranes; TGF- $\beta$, transforming growth factor beta immunohistochemical staining X40; arrow: Positive staining; VEGF, vascular endothelial growth factor immunohistochemical staining X40; arrow: Positive sta-

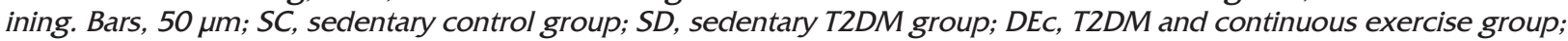
$D E s b, T 2 D M$ and short bouts exercise group; DEWw, T2DM and weekend warrior exercise group.

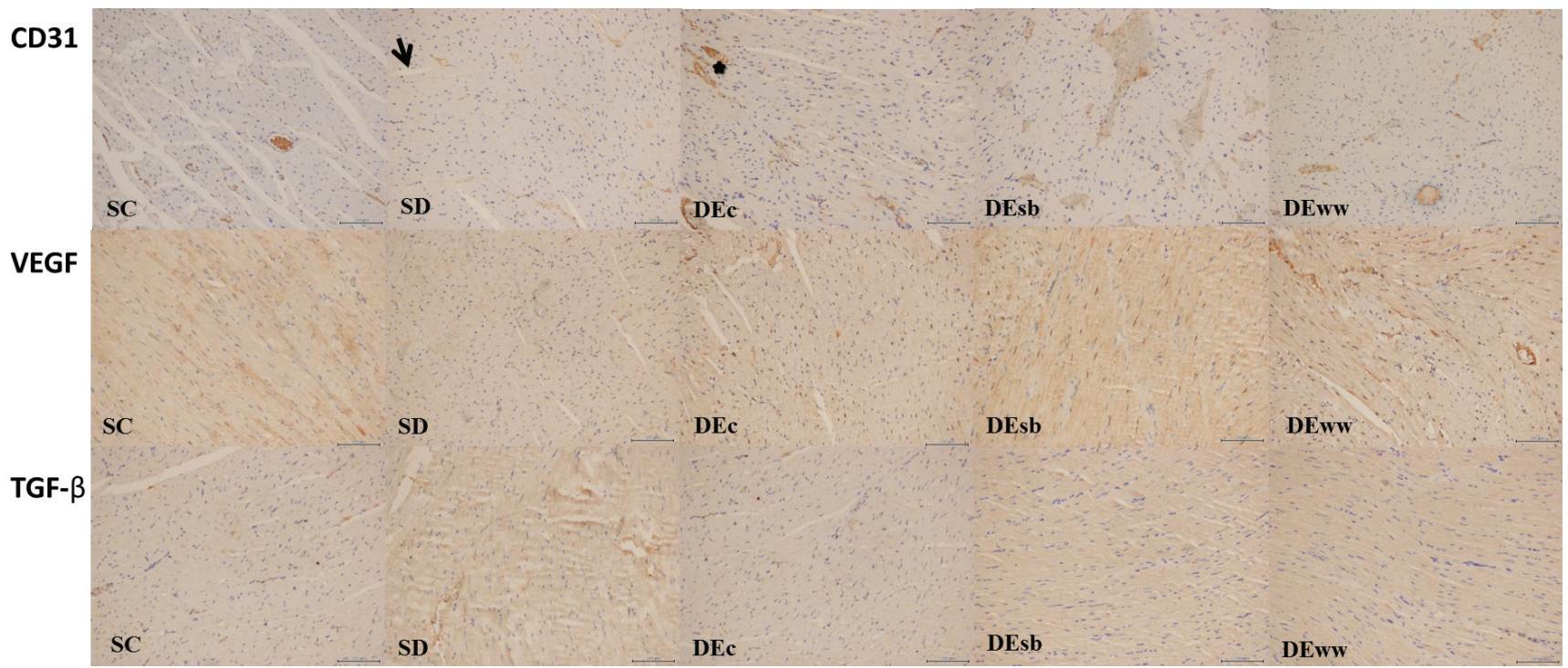

Figure 4. Effect of exercise frequencies on heart tissue of immunohistochemical staining in experimental type 2 diabetes induced rats.

$C D 31$ X20; arrow: negative staining; asterisk: positive staining; VEGF, vascular endothelial growth factor immunohistochemical staining X20; TGF- $\beta$, transforming growth factor beta immunohistochemical staining X20; Bars, $50 \mu$ m; SC, sedentary control group; SD, sedentary T2DM group; DEc, T2DM and continuous exercise group; DEsb, T2DM and short bouts exercise group; DEWW, T2DM and weekend warrior exercise group. 
A

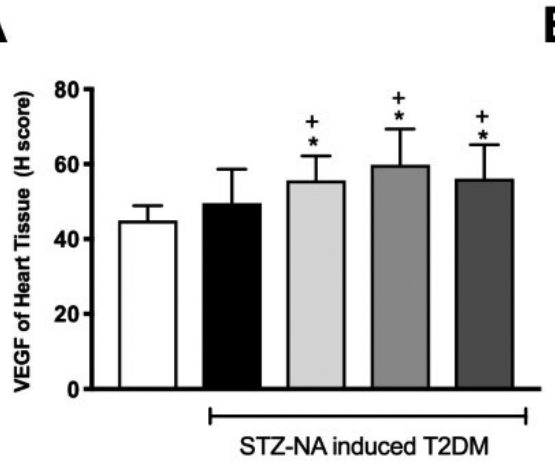

D

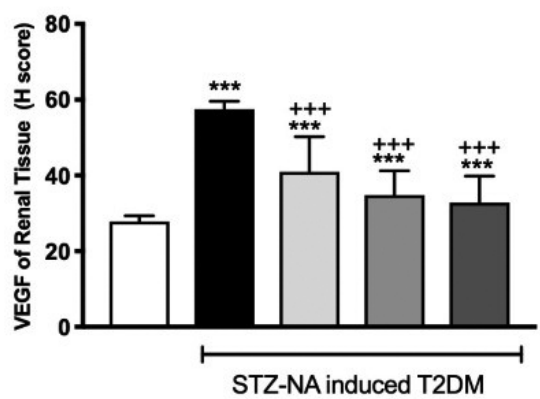

B

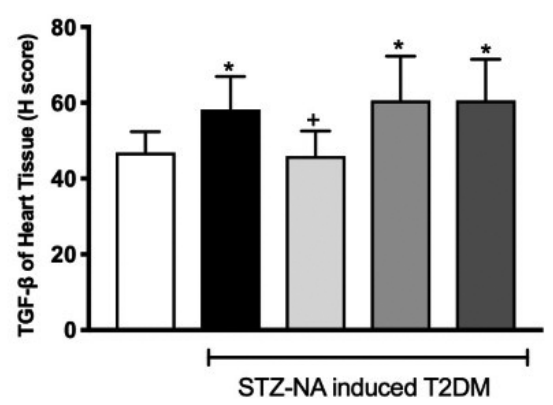

E

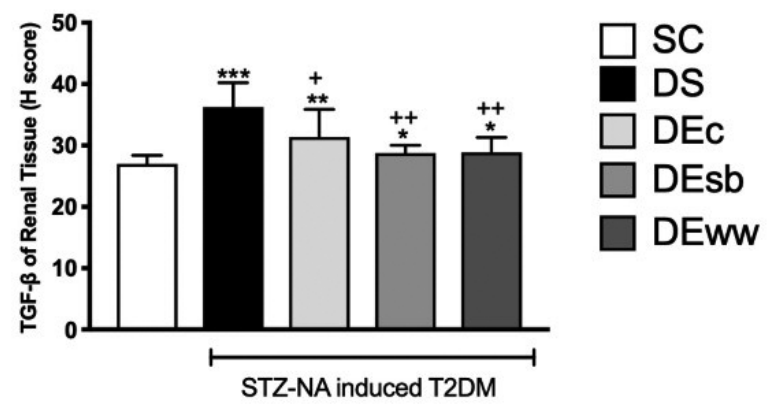

Figure 5. Effect of exercise frequencies on immunohistochemical staining in experimental type 2 diabetes induced rats. A: vascular endothelial growth factor (VEGF) of heart tissue, B: transforming growth factor beta (TGF- $\beta$ of heart tissue, C: capillar density (CD 31) of heart tisue; D: vascular endothelial growth factor (VEGF) of kidney tissue; E: transforming growth factor beta (TGF- $\beta$ of kidney tissue; SC, sedentary control group; SD, sedentary T2DM group; DEc, T2DM and continuous exercise group; $D E s b, T 2 D M$ and short bouts exercise group; DEWw, T2DM and weekend warrior exercise group. Data are reported as means $\pm S D$ of 6 animals in each group. " $p<0.05, "$, $p<0.01, "{ }^{\prime \prime \prime} p<0,001$ compared with sedentary control group. ${ }^{+} p<0.05,{ }^{++} p<0.01,{ }^{+++} p<0.001$ compared with sedentary T2DM group.

\section{DISCUSSION}

In this study, FBG on $8^{\text {th }}$ week, TNF- $\alpha$, IL-6, VEGF expressions in kidney tissue and TGF- $\beta$ expressions in heart and kidney tissue samples, cardiac fibrosis and renal basement membrane thickness were found to be increased in the SD group, while QUICKI, T-AOC and capillary density were lower compared to the SC group. In addition, glomerular architecture was completely disorganized, spaces between glomerular capillaries were narrowed, the mesangium was expanded, capsular area in the Bowman's capsule was narrowed and basement membranes were thickened in SD group. Howewer, favorable alterations were observed in all exercise groups. These effects include reduced levels of FBG on $8^{\text {th }}$ week, cardiac fibrosis, renal VEGF and TGF- $\beta$ expressions and reduced renal basement membrane thickness and increased QUICKI, T-AOC (except Group DEsb), cardiomyocyte size, cardiac VEGF expression and capillary density. Furthermore, in the kidney tissue, glomerular architecture was similar to the glomerular architecture in the SC group, spaces between glomerular capillaries and capsular area in the Bowman's capsule were enlarged and basement membrane was thinner compared to the basement membrane thickness in the SD group. In addition, TGF- $\beta$ level in the heart tissue was reduced only in the DEc group.

FBG was high at the end of 8th week in the SD group while decreases were observed in all exercise groups. These results were consistent with previous studies on the effects of exercise on $\mathrm{FBG}^{8,13}$. In addition, exercise is known to increase insulin sensitivity ${ }^{8}$. In our study, insulin sensitivity decreased in the SD group, in line with the 
literature, while statistically significant improvements were observed in all exercise groups indicating the improvement in insulin sensitivity following different exercise modalities. On the other hand, such reductions were not observed in OGTT measurements at $30^{\text {th }}$ and $60^{\text {th }}$ minutes. In studies employing genetically modified rats with longer exercise durations favorable effects of exercise on OGTT results were observed ${ }^{20,21}$. Some of these studies reported reduced FBG at $90^{\text {th }}$ and $120^{\text {th }}$ minutes ${ }^{22,23}$. FBG was not measured at these timepoints and this issue was the limitation of our study.

Although several studies have demonstrated that mild to moderate-intensity aerobic activity may lead to eccentric hypertrophy (elongated cells), there are studies reporting that aerobic activity of vigorous intensity may result in concentric hypertrophy (thick cells) ${ }^{24,25}$. A potential mechanism that may explain exercise-induced enhancement of contractile function of the heart may be the increase in cross-sectional area of the cardiac myocytes $^{25}$. In line with the literature, cardiomyocyte sizes were significantly increased in all exercise groups. However, unlike previous reports, cardiomyocyte sizes in the SD were similar to the cardiomyocyte sizes in the SC group. This may be due to the duration of induction period ( 6 weeks) in our study, since the time required to induce diabetic cardiomyopathy in a STZ-NA-induced diabetes model is 8 weeks, as previously suggested by Chang et al. ${ }^{26}$.

An association between cardiac fibrosis and diabetes has been reported by several authors ${ }^{27,28}$. Exercise has been reported to prevent the development of fibrosis which may also occur as a result of hyperglycemia and glycation end products $^{28}$. We also observed that, diabetes-induced fibrosis and regression of fibrosis were associated with a reduction in hyperglycemia in all exercise groups. Increasing evidence suggests that TGF- $\beta$ may play a critical role in the development and progression of myocardial fibrosis ${ }^{29}$. In our study, although TGF- $\beta$ expression was increased with the development of fibrosis in the SD group, a reduction in TGF- $\beta$ expression occurred in the sole DEc group among exercise groups.

In a study on STZ-induced Type 1 diabetes, Erekat et al. ${ }^{4}$ have demonstrated a reduction in VEGF expression in the diabetes group, which was not similar to the VEGF expression in the SD group in our study. This discrepancy may be related to the addition of NA to STZ which might lead to a moderate and more stable hyperglycemia. In line with our study, VEGF levels were increased in all exercise groups in that study. VEGF is an important moderator of physiological and pathophysiological conditions in angiogenesis, namely the growth of new capillaries from preexisting microvessels. Exercise-related increases in VEGF and decreased capillary density in the SD group and increased capillary density in the exercise groups mutually support each other. Aerobic exercise-related increases in the number of myocardial vessels in the LV have been reported to result from a balance mechanism similar to that of skeletal muscle ${ }^{30}$. This finding was apparent in all exercise groups; therefore, not one single group proved superior over others.

Exercise results in hemodynamic alterations as well as alterations in renal protein excretion and decreases renal blood flow and glomerular filtration rate. Furthermore, acute exercise is known to increase urinary protein excretion while the effects of acute exercise on diabetic nephropathy have remained controversial. Exercise has been reported to have favorable effects on nephropathy and these effects are probably associated with exercise related reduction in hyperglycemia ${ }^{31}$. Moreover, De Moraes et al. ${ }^{32}$ have demonstrated that exercise might prevent harmful effects of high glucose levels. They reported that exercise may have a modulator role in hyperglycemia, and may prevent the progression of diabetic nephropathy in spite of possible hemodynamic alterations in the kidney. In our study, FBG levels were also 
reduced in the exercise groups. In addition, aerobic exercise has been reported to have favorable effects on oxidative stress which might further contribute to its renoprotective effects ${ }^{31}$. Similarly, total antioxidant levels were reduced in the SD group and increased in the exercise groups (except the DEsb group). In addition, histopathological distortion of the kidney tissue was observed in the SD group while the opposite was applicable for the exercise groups. Basement membrane thickness and TGF- $\beta$ expressions were increased in the SD group whereas they were reduced in the exercise groups. In a study conducted by Ren et al. ${ }^{33}$ moderate-intensity exercise was reported to reduce increased TGF- $\beta$ levels and prevent the progression of kidney disease by modulating TGF- $\beta$-induced epithelial-mesenchymal transition in kidneys in T2DM. TGF- $\beta$ is an important modulator of extracellular matrix accumulation and the development of fibrosis, in particular. Exercise particularly reduces hyperglycemia and glycation end products and consequently reduces stimulations triggering TGF- $\beta$ production. Thus, we consider this effect as one of the favorable renal effects of exercise at frequencies investigated in this study.

VEGF plays a role in the pathogenesis of a number of kidney diseases including diabetic nephropathy, associated with high protein diets and glomerulonephritis. VEGF expression has a role in the pathogenesis of diabetic nephropathy. VEGF upregulation has been reported in diabetic kidney tissue similar to our study ${ }^{5}$. In a study conducted by Al-Jarrah et al. ${ }^{34}$ rats were given treadmill exercise at a speed of $18 \mathrm{~m} / \mathrm{min} 40 \mathrm{~min} /$ day for 5 days/week and diabetes-related elevation of VEGF levels declined. In our study, VEGF expression declined in the exercise groups, in line with the literature. Furthermore, moderate-intensity exercise has been reported to reduce advanced glycation end products and ameliorate early diabetic nephropathy in obese Zucker rats ${ }^{35}$. Therefore, we agree with the conclusion that exercise training may reduce VEGF upregulation in diabetic kid- neys by reducing hyperglycemia and increasing insulin sensitivity ${ }^{34}$. Similar favorable alterations occurred in kidney tissue in response to exercise performed at various frequencies.

\section{CONCLUSION}

This study suggests that physical activity at various frequencies may significantly ameliorate harmful effects of T2DM on heart and kidney tissue without significant differences between exercise frequencies, including continuous, short bout or weekend warior alone, provided that total duration of weekly exercise (a total of 150 minutes of aerobic swimming exercise) remains the same.

\section{Acknowledgements}

This research work was supported by the Mehmet Ali Aydinlar Acibadem University Scientific Research Project Commission (Project no. 2017/01/13).

\section{REFERENCES}

1. Heller GV. Evaluation of the patient with diabetes mellitus and suspected coronary artery disease. Am J Med Suppl. 2005;18:9-14. [CrossRef]

2. Kurdak H, Sandikci S, Ergen N, Dogan A, Kurdak SS. The effects of regular aerobic exercise on renal functions in streptozotocin induced diabetic rats. J Sport Sci Med. 2012;9:294. Available from: https://www.ncbi.nlm.nih. gov/pmc/articles/PMC3761734/pdf/jssm-09-294.pdf.

3. Bernatchez PN, Soker S, Sirois MG. Vascular endothelial growth factor effect on endothelial cell proliferation, migration, and platelet-activating factor synthesis is Flk-1dependent. J Biol Chem. 1999;274:31047-54. [CrossRef]

4. Erekat NS, Al-Jarrah MD, Al Khatib AJ. Treadmill exercise training improves vascular endothelial growth Factor expression in the cardiac muscle of type I diabetic rats. Cardiol Res. 2014;5:23-9. [CrossRef]

5. Mironidou-Tzouveleki M, Tsartsalis S, Tomos C. Vascular endothelial growth factor (VEGF) in the pathogenesis of diabetic nephropathy of type 1 diabetes mellitus. Current drug targets. 2011;12:107-14. [CrossRef]

6. Cheng AY, Canadian Diabetes Association Clinical Practice Guidelines Expert Committee. Canadian Diabetes Association 2013 clinical practice guidelines for the prevention and management of diabetes in Canada. Introduction. Can J Diabetes. 2013;37:S1. [CrossRef]

7. Sigal RJ, Kenny GP, Wasserman DH, Castaneda-Sceppa C. Physical activity/exercise and type 2 diabetes. Diabetes Care. 2004;27:2518-39. [CrossRef]

8. Alaca N, Uslu S, Gulec Suyen, G, Ince U, Serteser M, Kurtel $\mathrm{H}$. Effects of different aerobic exercise frequencies 
on streptozotocin-nicotinamide-induced type 2 diabetic rats: Continuous versus short bouts and weekend warrior exercises. J Diabetes. 2018;10:73-84. [CrossRef]

9. Eriksen L, Dahl-Petersen I, Haugaard SB, Dela F. Comparison of the effect of multiple short-duration with single long-duration exercise sessions on glucose homeostasis in type 2 diabetes mellitus. Diabetologia. 2007;50: 224553. [CrossRef]

10. Murphy MH, Blair SN, Murtagh EM. Accumulated versus Continuous Exercise for Health Benefit A Review of Empirical Studies. Sports Med. 2009;39:29-43. [CrossRef]

11. Haskell WL, Lee IM, Pate RR, Bauman A. Physical activity and public health: updated recommendation for adults from the American College of Sports Medicine and the American Heart Association. Circulation. 2007;1 16:1081. [CrossRef]

12. Shuval K, Hébert ET, Siddiqi Z, Skinner CS. Impediments and facilitators to physical activity and perceptions of sedentary behavior among urban community residents: the Fair Park Study. PCD. 2013;10:E177. [CrossRef]

13. Uslu S, Alaca N, Kilic KD, Uysal A, Kurtel H. The effects of aerobic exercise frequencies on liver fibrosis, \-fetoprotein and cytokeratin 19 in experimental type 2 diabetes-induced rats: an immunohistochemistry study. Biotech Histochem. 2018;93:615-22. [CrossRef]

14. Kakadiya J, Shah M, Shah NJ. Effect of nebivolol on serum diabetic marker and lipid profile in normal and streptozotocin-nicotinamide induced diabetic rats. Res J Pharm Biol Chem Sci.2010;1:329-34. Available from: https:// www.rjpbcs.com/pdf/Old\%20files/46.pdf

15. Toma A, Makonnen E, Mekonnen Y, Debella A, Adisakwattana S. Antidiabetic activities of aqueous ethanol and $\mathrm{n}$-butanol fraction of Moringa stenopetala leaves in streptozotocin-induced diabetic rats. BMC Compl Alternative Med. 2015;15:242. [CrossRef]

16. Kumar AY, Nandakumar K, Handral M, Talwar S, Dhayabaran D. Hypoglycaemic and anti-diabetic activity of stem bark extracts Erythrina indica in normal and alloxan-induced diabetic rats. Saudi Pharmaceutical Journal. 2011;19:35-42. [CrossRef]

17. Katz A, Nambi SS, Mather K, et al. Quantitative insulin sensitivity check index: a simple, accurate method for assessing insulin sensitivity in humans. J Clin Endocrinol Metab. 2000;85:2402-10. [CrossRef]

18. Turgut M, Uslu S, Uysal A, Yurtseven ME, Üstün H. Changes in vascularity of cartilage endplate of degenerated intervertebral discs in response to melatonin administration in rats. Neurosurg Rev. 2003;26:133-8. [CrossRef]

19. Uslu S, Oktem G, Uysal A, Soner BC, Arbak S, Ince U. Stem cell and extracellular matrix-related molecules increase following melatonin treatment in the skin of postmenopausal rats. Cell Biol Int. 2014;38:924-32. [CrossRef]

20. Becker-Zimmermann K, Berger M, Berchtold P, Gries FA, Herberg L, Schwenen M. Treadmill training improves intravenous glucose tolerance and insulin sensitivity in fatty Zucker rats. Diabetologia. 1982;22:46874. Available from: https://link.springer.com/content/ pdf/10.1007\%2FBF00282592.pdf [CrossRef]

21. Ishizawa $K$, Yoshizumi $M$, Tsuchiya $K$, et al. Effects of losartan in combination with or without exercise on insu- lin resistance in Otsuka Long-Evans Tokushima Fatty rats. Eur J Pharmacol. 2001;430:359-67. [CrossRef]

22. Rönnemaa T, Mattila K, Lehtonen A, Kallio V. A controlled randomized study on the effect of long-term physical exercise on the metabolic control in type 2 diabetic patients. Acta Med Scand. 1986;220:219-24. [CrossRef]

23. Tokmakidis SP, Zois CE, Volaklis KA, Kotsa K, Touvra AM. The effects of a combined strength and aerobic exercise program on glucose kontrol and insulin action in women with type 2 diabetes. Eur J Appl Physiol. 2004;92:437-2. [CrossRef]

24. Natali AJ, Wilson LA, Peckham M, Turner DL, Harrison $\mathrm{SM}$, White E. Different regional effects of voluntary exercise on mechanical and electrical properties of rat ventricular myocytes. J Physiol. 2002;541:863-75. [CrossRef]

25. Natali AJ. Effects of chronic exercise on cardiac myocytes:a review about mechanical adaptations. R. bras. Cie Mov. 2004;12:91-6. Available from: http://bases.bireme.br/ cgi-bin/wxislind.exe/iah/online

26. Chang KC, Tseng CD, Chou TF, et al. Arterial stiffening and cardiac hypertrophy in a new rat model of type 2 diabetes. Eur J Clin Investig. 2006;36:1-7. [CrossRef]

27. Eckel RH, Kahn SE, Ferrannini E, et al. Obesity and type 2 diabetes: what can be unified and what needs to be individualized? The JCEM. 2011 ;96:1654-63. [CrossRef]

28. Wang H, Bei Y, Lu Y, et al. Exercise prevents cardiac injury and improves mitochondrial biogenesis in advanced diabetic cardiomyopathy with PGC-1冈 and Akt activation. Cell Physiol Biochem. 2015;35:2159-68. [CrossRef]

29. Ma Y, Zou H, Zhu XX, et al. Transforming growth factor $\unrhd$ : A potential biomarker and therapeutic target of ventricular remodeling. Oncotarget. 2017;8:53780-90. [CrossRef]

30. Pimenta L, Gama EF, Maifrino LBM, De Souza RR. Effects of physical exercises on the ventricular myocardium. Braz J Morphol Sci. 2009;26:113-7. Available from: http://s3.amazonaws.com/host-article-assets/ jms/587cb48e7f8c9d0d058b4741/fulltext.pdf

31. Lu J, Yao YY, Dai QM, et al. Erythropoietin attenuates cardiac dysfunction by increasing myocardial angiogenesis and inhibiting interstitial fibrosis in diabetic rats. Cardiovasc Diabetol. 2012;11:105. [CrossRef]

32. De Moraes R, Gioseffi GL, Nuno do N, Gomes MB, Nóbrega AC, Lucas TE. Exercise training protects the renal circulation against high glucose challenge. Fund Clin Pharmacol. 2005;19:537-43. [CrossRef]

33. Ren L, Sen U, Pushpakumar S: Exercise training reduces TGF- $\triangle$ mediated epithelial mesenchymal transition in diabetic kidney. The FASEB. 2017;31 Available from: Supp:1086-5. https://www.fasebj.org/doi/abs/10.1096/ fasebj.31.1_supplement.1086.5

34. Al-Jarrah M, Erekat N, Al Khatib A. Upregulation of Vascular Endothelial Growth Factor Expression in the Kidney Could Be Reversed Following Treadmill Exercise Training in Type I Diabetic Rats. WJNU. 2014;3:25-9. [CrossRef]

35. Boor P, Celec P, Behuliak M, et al. Regular moderate exercise reduces advanced glycation and ameliorates early diabetic nephropathy in obese Zucker rats. Metabolism. 2009;58:1669-77. [CrossRef] 